\title{
Purification of infectious canine parvovirus from cell culture by affinity chromatography with monoclonal antibodies*
}

\author{
G.F. Rimmelzwaan ${ }^{1}$, J. Groen ${ }^{1}$, N. Juntti², J.S. Teppema ${ }^{1}$, F.G.C.M. \\ UytdeHaag' $^{1}$ and A.D.M.E. Osterhaus ${ }^{1}$ \\ ${ }^{1}$ National Institute of Public Health and Environmental Hygiene. Bilthoven, the Netherlands; and \\ 'National Veterinary Institute Biomedical Centre. Uppsala, Sweden
}

(Accepted 14 November 1986)

Immuno affinity chromatography with virus neutralizing monoclonal antibodies. directed to the haemagglutinating protein of canine parvovirus (CPV) was used to purify and concentrate CPV from infected cell culture. The procedure was monitored by testing the respective fractions in an infectivity titration system, in an ELISA, in a haemagglutination assay and by negative contrast electron microscopy to quantify CPV or CPV antigen. The degree of purification was further estimated by testing the fractions for total protein content in a colorimetric method, for bovine serum albumin content in an ELISA and by SDS-PAGE. Over $99 \%$ of the contaminating proteins proved to be removed, and $20 \%$ or $70-90 \%$ of infectious CPV or CPV antigen. respectively, was recovered.

Canine parvovirus: Purification: Immuno affinity chromatography; Monoclonal antibody

\section{Introduction}

Canine parvovirus (CPV) is a nonenveloped single-stranded DNA virus that may cause an occasionally fatal enteritis-panleukopenia syndrome in dogs (Appel et al., 1979; Gagnon and Povey, 1979; Johnson and Spradbrow, 1979; Osterhaus et al., 1980). Purified CPV derived from culture supernatant of CPV-infected cells has been used for biochemical (Paradiso, 1982; Rhode, 1985), ultrastructural (Paradiso, 1982), immunological (Parrish et al., 1982; Burtonboy et al., 1982; Parrish and Carmichael, 1983) and serological (Fiscus et al., 1985) studies. Conventional methods used for the purification of parvoviruses from cell culture supernatant,

\footnotetext{
* This work was supported in part by the 'Bond tot Bescherming van Honden', The Hague, Netherlands.

Correspondence to: G.F. Rimmelzwaan, National Institute of Public Health and Environmental Hygiene, Bilthoven, the Netherlands.
} 
including $\mathrm{CaCl}_{2}$ precipitation (Tattersall et al., 1976), polyethylene glycol precipitation (Paradiso, 1981), banding in isopycnic $\mathrm{CsCl}$ gradients (Tattersall et al., 1976; Paradiso, 1981; Parrish et al., 1982) and haemadsorption elution (Osterhaus et al., 1980; Burtonboy et al., 1982), are multi-step and time-consuming procedures which are difficult to apply to large-scale purification. Immuno affinity chromatography (IAC) using monoclonal antibodies (MoAbs) has been shown to be a suitable method for the purification of viruses or viral antigens (Chong et al., 1985; Diaco et al., 1986). Virus purification from tissues infected with Aleutian mink disease virus, a member of the Parvoviridae family, by IAC using a polyclonal antibody preparation has been described (Kenyon et al., 1973).

In the present study, we describe the purification and concentration of CPV by IAC using mouse MoAbs directed against the haemagglutinating $(\mathrm{H})$ protein of CPV, immobilized to Sepharose. The method proved efficient and relatively simple to concentrate and purify CPV from infected cell culture.

\section{Materials and Methods}

\section{Virus}

The continuous canine cell line A-72 (Binn et al., 1980) was cultivated in Eagle's medium supplemented with Hanks' salts, lactalbumine hydrolysate $(5.13 \mathrm{~g} / \mathrm{l})$, natriumcarbonate $350 \mathrm{mg} / \mathrm{l}$, glutamine $0.002 \mathrm{M}, 100 \mathrm{IU}$ penicillin $/ \mathrm{ml}, 100 \mu \mathrm{g}$ streptomycin $/ \mathrm{ml}$, and $10 \%$ fetal calf serum in $850 \mathrm{~cm}^{2}$ roller bottles (Costar) rolling at $0.4 \mathrm{rpm}$ at $37^{\circ} \mathrm{C}$. Complete monolayers were trypsinized, washed and resuspended in phosphate-buffered saline (PBS) (pH 7.4).

The resuspended cells $\left(10^{7}\right.$ per $\mathrm{ml}$ ) were infected with CPV (strain C780916; Carmichael et al., 1981) at a m.o.i. of about $10^{-3} \mathrm{TCID}_{50}$ per cell, by incubating the cells with CPV in a rolling bottle for $90 \mathrm{~min}$ at $37^{\circ} \mathrm{C}$. After low speed centrifugation, the cells were resuspended in culture medium and cultivated at $37^{\circ} \mathrm{C}$ in roller bottles. Four to five days postinfection, the cultures exhibiting cytopathic changes were frozen and thawed twice. The suspension was clarified by centrifugation for $15 \mathrm{~min}$ at $2000 \times \mathrm{g}$ and used as starting material for IAC.

\section{Production and characterization of MoAbs}

A panel of hybridomas producing MoAbs reactive with the $\mathrm{H}$ protein of $\mathrm{CPV}$ was generated essentially as previously described for the generation of MoAbs against poliovirus (Osterhaus et al., 1981). Briefly, spleen cells from BALB/c mice immunized with CPV were fused with a mouse myeloma cell line. Hybridomas producing MoAbs, positive in haemagglutination inhibition (HI) and virus neutralization (VN) tests (see below), were selected and single cell cloned twice. Mouse ascitic fluids were produced in $\mathrm{BALB} / \mathrm{c}$ mice. Ig was isolated from mouse ascitic fluids by precipitation with ammonium sulphate and affinity chromatography using Protein A-Sepharose (Pharmacia Fine Chemicals, Uppsala, Sweden) (Seppälä et 
al., 1981; Manil et al., 1986). Purified antibodies were conjugated to horseraddish peroxidase (HRP) according to standard methods (Nakane and Kawaoi, 1974).

The epitope specificity of the MoAbs was determined in a competition ELISA system on CPV-coated microtiter plates (Titertek, Flow Laboratories). For this ELISA, CPV was coated in an optimal dilution in $0.1 \mathrm{M}$ sodium carbonate buffer ( $\mathrm{pH}$ 9.6). After washing with demineralized water containing $0.05 \%$ Tween 80 (Merck, Schuchardt, F.R.G.) (DWT), 100- $\mu$ l volumes of 10 -fold dilutions of unconjugated antibodies (ascitic fluids) were made in PBS containing 1\% bovine serum albumin (BSA) (Organon Techika, Oss, The Netherlands) and $0.05 \%$ Tween 80 and incubated for $30 \mathrm{~min}$ at room temperature. The plates were washed with DWT and homologous or heterologous HRP-conjugated MoAbs were added at the appropriate dilutions and incubated for $30 \mathrm{~min}$. The plates were washed twice and $100 \mu \mathrm{l}$ of substrate solution $(0.1 \mathrm{mg} / \mathrm{ml}$ tetramethylbenzidine [TMB] $)$ and $0.003 \% \mathrm{H}_{2} \mathrm{O}_{2}$ in $0.1 \mathrm{M} \mathrm{NaAc}$ buffer ( $\mathrm{pH} \mathrm{5.5)}$ was added to each well. After $10 \mathrm{~min}$ at room temperature, $100 \mu \mathrm{l}$ of $2 \mathrm{M} \mathrm{H}_{2} \mathrm{SO}_{4}$ was added to stop the reaction. The absorbance at $450 \mathrm{~nm}$ was read in a Titertek Multiskan (Titertek, Flow Laboratories).

Isotypes of the MoAbs were determined in an ELISA system. For this ELISA, Protein A-purified anti-CPV MoAbs were diluted in PBS containing 1\% BSA (Organon Technika) and $0.05 \%$ Tween 80 (Merck) and incubated for $30 \mathrm{~min}$ in wells of CPV-coated microtiter plates (Titertek, Flow Laboratories). After washing, $100 \mu \mathrm{l}$ of rabbit anti-mouse antibody preparations, specific IgGl, IgG2a, IgG2b, IgG3, IGM or IgA (Litton Bionetics, Charleston, U.S.A.), were added in 1:1000 dilutions and incubated for another $30 \mathrm{~min}$. After washing, $100 \mu \mathrm{l}$ swine anti-rabbit HRP-conjugated antibody (Dakopatts, Denmark) was added in a 1:1000 dilution and incubated for $30 \mathrm{~min}$. The plates were washed and developed with TMB substrate as described above.

\section{IAC chromatography}

Protein A-Sepharose IAC-purified MoAbs were dialysed against coupling buffer and coupled to $\mathrm{CNBr}$-activated Sepharose 4-B (20 mg McAb to $10 \mathrm{ml}$ gel volume) as recommended by the manufacturer (Pharmacia Fine Chemicals). The column was equilibrated with TEN buffer $(20 \mathrm{mM}$ Tris, $1 \mathrm{mM}$ EDTA, $0.15 \mathrm{M} \mathrm{NaCl}$ adjusted to $\mathrm{pH} 7.8$ with $\mathrm{HCl}$ ). To $90 \mathrm{ml}$ of clarified culture supernatant from CPVinfected cells $10 \mathrm{ml}$ of a 10 times concentrated TEN buffer was added together with solid $\mathrm{NaCl}$ to a final concentration of $0.65 \mathrm{M} \mathrm{NaCl}$.

CPV was allowed to bind overnight by running the column at low speed $(20 \mathrm{ml} / \mathrm{h})$. After washing the column with $20-30 \mathrm{ml}$ TEN buffer supplemented with $0.5 \mathrm{M} \mathrm{NaCl}$, the virus was eluted with TEN buffer containing $3 \mathrm{M} \mathrm{NH}_{4} \mathrm{SCN}$ and dialysed against PBS. All steps were carried out at $4^{\circ} \mathrm{C}$.

Effluent (unbound material) and eluate fractions were tested in SDS-PAGE and in the respective biological assays (see below). Protein concentrations were determined by the colorimetric method of Bradford (Bradford, 1976) adapted to a microtiter system. 
Double antibody sandwich ELISA

For the detection and quantification of CPV antigen, a double antibody sandwich ELISA was used. Microtiter plates were coated with two Protein A-purified MoAbs (H-1 and H-2) which recognize two different epitopes (see below), 100- $\mu$ l volumes containing $250 \mathrm{ng}$ of each MoAb were incubated in microtiter plates for $16 \mathrm{~h}$ at $4^{\circ} \mathrm{C}$. After washing with DWT, $150-\mu \mathrm{l}$ volumes of a $1 \%$ BSA solution containing $0.1 \% \mathrm{NaN}_{3}$ in distilled water were added. The plates were sealed and stored at $4^{\circ} \mathrm{C}$ until use.

Plates were washed with DWT and 50- $\mu$ l volumes of 3-fold serial dilutions of CPV suspensions were added simultaneously with $50 \mu$ l of HRP-conjugated MoAbs $\mathrm{H}-1$ and $\mathrm{H}-2$. After incubation for $30 \mathrm{~min}$ at $37^{\circ} \mathrm{C}$, the plates were washed twice and developed with TMB substrate.

\section{$H A$ and $H I$ tests}

HA and HI tests were performed in 96-well round bottom microtiter plates as described (Appel et al., 1979; Carmichael et al., 1980; Osterhaus et al., 1980a), using African green monkeys (Cercopithecus aethiops) erythrocytes.

\section{Infectivity and $V N$ tests}

For infectivity titrations, $1.8-\mathrm{ml}$ volumes of 10 -fold dilutions of CPV preparations in PBS were mixed with $0.9-\mathrm{ml}$ volumes of a suspension containing $8 \times 10^{5}$ A-72 cells per $\mathrm{ml}$ in PBS. The mixtures were incubated for $90 \mathrm{~min}$ at $37^{\circ} \mathrm{C}$ and gently agitated every $15 \mathrm{~min}$. Cells were pelleted by low speed centrifugation, resuspended in 5.4-ml culture medium and divided over eight Lab Tek chambers (Miles, Napperville, U.S.A.). After 4 days of cultivation at $37^{\circ} \mathrm{C}$, cells were fixed with ethanol at $-70^{\circ} \mathrm{C}$ and examined by immuno fluorescence using one of the Protein A-purified anti-CPV MoAb and a FITC-conjugated swine anti-mouse preparation (Nordic, Tilburg, The Netherlands). For VN tests, the same procedure was followed: after incubation for $1 \mathrm{~h}$ at $20^{\circ} \mathrm{C}$ of $100 \mathrm{TCID}_{50} \mathrm{CPV}$ with dilutions of the respective MoAbs.

\section{Electron microscopy}

For negative contrast examination, small drops of the samples to be tested were placed on formvar/carbon-coated grids and contrasted with $2 \%$ phosphotungstic acid (adjusted to $\mathrm{pH} 2.5$ with $\mathrm{KOH}$ ). The preparations were examined in a Philips EM 400T transmission electron microscope. 
Cell culture harvests and column fractions were tested for BSA content in an ELISA using an anti-BSA mouse MoAb (IgGl) coupled to HRP (Avest and Osterhaus, submitted for publication). In short, samples were coated to microtiter plates in serial 10 -fold dilutions in sodium carbonate buffer $\left(\mathrm{pH} \mathrm{9.6)} \mathrm{for} 2 \mathrm{~h}\right.$ at $37^{\circ} \mathrm{C}$. After washing, $100 \mu \mathrm{l}$ of a 1:3000 dilution of the anti-BSA conjugate in PBS containing $0.05 \%$ Tween and $0.25 \%$ ovalbumine (Sigma Chemical, St. Louis, MO). Plates were washed and developed with TMB as described above. For the determination of BSA content, ELISA values were compared with those obtained with standard dilutions of a BSA (Boseral, Organon, Oss, The Netherlands) preparation.

SDS-PAGE

Proteins were analysed on $12 \%$ polyacrylamide slab gels (Laemmli, 1970). Gels were silverstained (Wray et al., 1981). Proteins of known molecular weights (BioRad, Richmond, U.S.A.) were included to estimate the molecular weights of viral proteins.

\section{Results}

MoAbs

A panel of four stable hybridomas producing HI-positive VN MoAbs ( $\mathrm{H}-1, \mathrm{H}-$ $2, \mathrm{H}-3$ and $\mathrm{H}-4$ ) were selected. These MoAbs also reacted with the haemagglutinin of feline panleukopenia virus (FPV) and recognized at least two different epitopes as was demonstrated in the competition ELISA (Table 1). The isotypes of the four MoAbs proved to be IgG2a, IgG2b, IgG1 and IgG2b, respectively (Table 1). MoAbs $\mathrm{H}-1$ and $\mathrm{H}-2$ were used in further IAC purification studies.

$I A C$

Two small Sepharose 4-B columns (bed volume $1.0 \mathrm{ml}$ ) were prepared with MoAbs $\mathrm{H}-1$ and $\mathrm{H}-2$, respectively, which were shown to recognise different epitopes (Table 1). When $10 \mathrm{ml}$ of CPV-infected culture material (HA titer 1024; double antibody sandwich ELISA titer 30) were passed through either of the columns, no infectious CPV or CPV antigen (ELISA/HA) could be detected in the effluent material of the columns. Upon elution with $3 \mathrm{M} \mathrm{NH}_{4} \mathrm{SCN}, \mathrm{CPV}$ antigen could be eluted from both columns with about the same efficiency, as judged from ELISA and HA titrations carricd out with the respective fractions collected from both columns. The profiles obtained in HA and ELISA coincided well with those obtained with the 10-ml bed volume column described below (not shown). To investigate further the potential of the IAC procedure for the purification and con- 
TABLE 1

Properties of anti-CPV MoAbs.

\begin{tabular}{|c|c|c|c|c|c|}
\hline \multirow[t]{3}{*}{$\mathrm{MoAb}$} & \multicolumn{4}{|c|}{$\log ^{10}$ titer in competition ELISA } & \multirow[t]{3}{*}{ isotype } \\
\hline & \multicolumn{4}{|c|}{ HRP-conjugate } & \\
\hline & $\mathrm{H}-1$ & $\mathrm{H}-2$ & $\mathrm{H}-3$ & $\mathrm{H}-4$ & \\
\hline H-1 & 2 & $-^{*}$ & 2 & 2 & $\mathrm{IgG} 2 \mathrm{a}$ \\
\hline $\mathrm{H}-2$ & - & 4 & - & - & $\operatorname{IgG} 2 b$ \\
\hline $\mathrm{H}-3$ & - & - & 4 & 2 & $\operatorname{IgG1}$ \\
\hline $\mathrm{H}-4$ & 4 & - & 4 & 4 & $\operatorname{IgG} 2 b$ \\
\hline
\end{tabular}

$*-: \leqslant 1$.

centration of CPV from cell culture material, a $10-\mathrm{ml}$ bed volume affinity column was prepared with MoAb H-1. When $100 \mathrm{ml}$ of the CPV-infected culture material were passed through this column again, neither CPV nor CPV antigen could be detected by HA, ELISA or infectivity assays in the effluent (Fig. 1), and no or only few irregular parvovirus-like particles were observed by negative contrast electron microscopy (Fig. 2). The effluent contained relatively high concentrations of contaminating proteins (up to about $4 \mathrm{mg} / \mathrm{ml}$ ) including $\mathrm{BS} \Lambda$ as was also visualized by SDS-PAGE in the initial effluent fractions (Fig. 3), which gradually de-

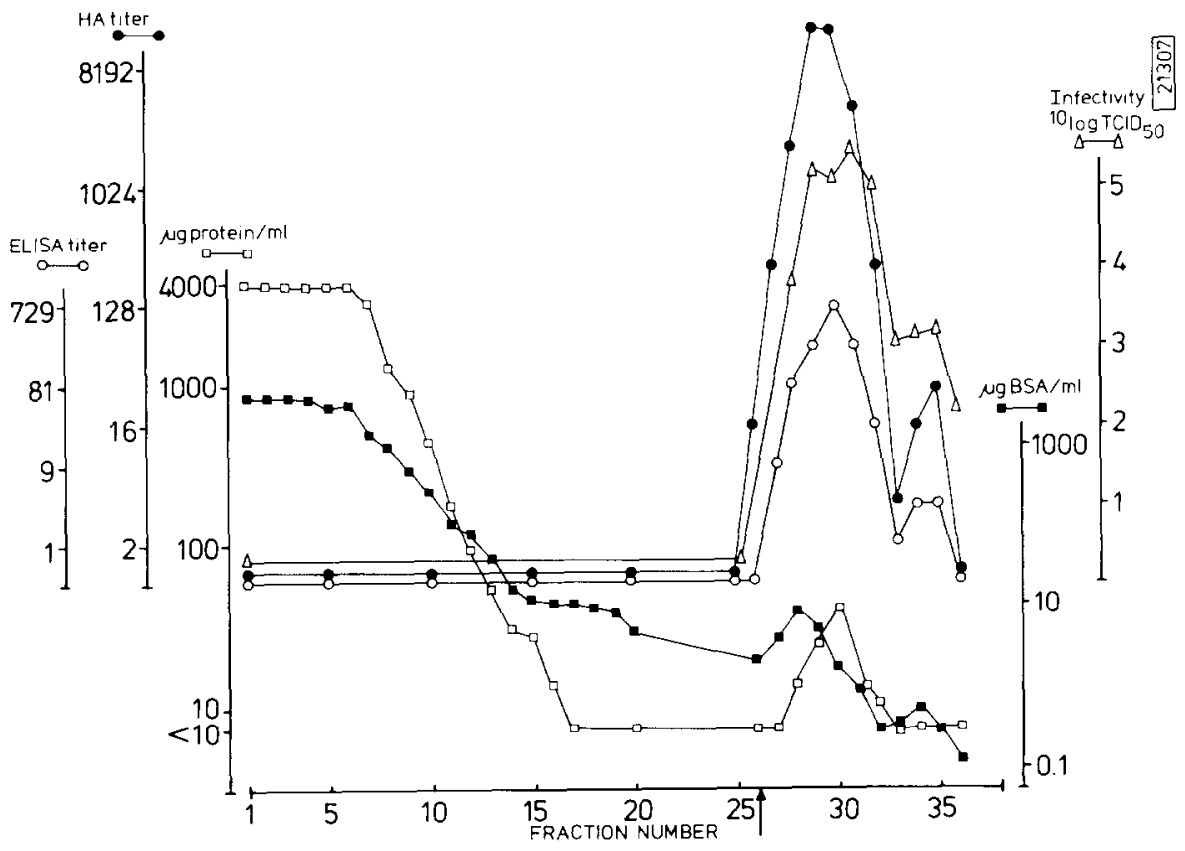

Fig. 1. Purification of CPV by IAC. Arrow indicates change of buffers. Fractions were collected and monitored for ELISA reactivity $\left(\bigcirc_{-}\right)$, haemagglutination activity $(\bullet \bullet)$, protein content, $(\square-\square)$, BSA content, (ロ- ) and infectivity $(\triangle-\triangle)$. 


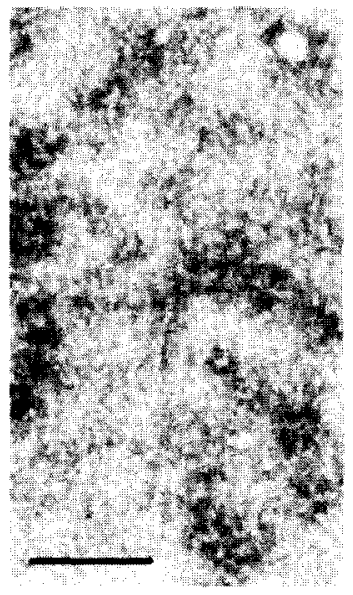

Fraction number 4

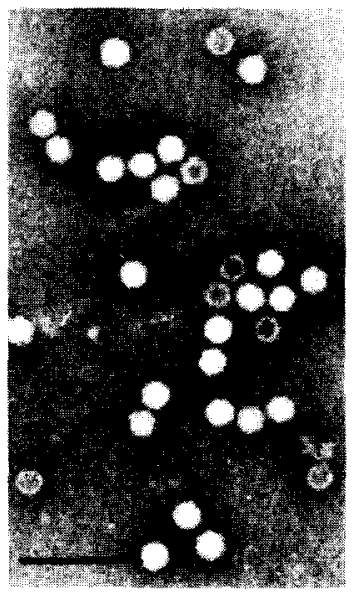

Fraction number 30

Fig. 2. Analysis of effluent and eluate fractions by electron microscopy. $(123.000 \times)$. Bar represents $100 \mathrm{~nm}$.

clined upon washing the column with the starting buffer (Fig. 1). CPV and/or CPV antigen could be readily recovered from the column by elution with $3 \mathrm{M} \mathrm{NH}_{4} \mathrm{SCN}$, as was shown by titration in infectivity assays, HA, and ELISA of the eluate fractions (Fig. 1, Table 2). On the basis of the titers found in the respective assays, it was concluded that a recovery of about $20 \%$ of infectious CPV, and of about $70-90 \%$ of CPV antigen could be achieved, and that maximal concentration effects of about four and 16 times, respectively, were obtained. Analysis of eluate fractions by negative contrast electron microscopy confirmed the presence of large numbers of predominantly full virus particles, apparently free from contaminating membranous structures, in the fractions with the highest CPV and CPV antigen concentrations (Fig. 2). Total protein and BSA concentrations in these peak fractions measured about 40 and $8 \mu \mathrm{g} / \mathrm{ml}$, respectively. In eluate peak fractions, only three protein bands could be visualized by SDS-PAGE at molecular weights corresponding to those of parvovirus proteins: $82.5 \cdot 10^{3}, 67.5 \cdot 10^{3}$ and $65 \cdot 10^{3}$, respectively (Fig. 3).

The column could be used more than 20 times without apparent loss its of binding capacity. This capacity proved at least three times higher than the amount of antigen used in the experiments mentioned above.

\section{Discussion}

In the present paper, we show that IAC, using a MoAb directed against the $\mathrm{H}$ protein of $\mathrm{CPV}$, provides a rapid and relatively simple procedure for the purification and concentration of CPV from cell culture material. Analysis of the frac- 
A

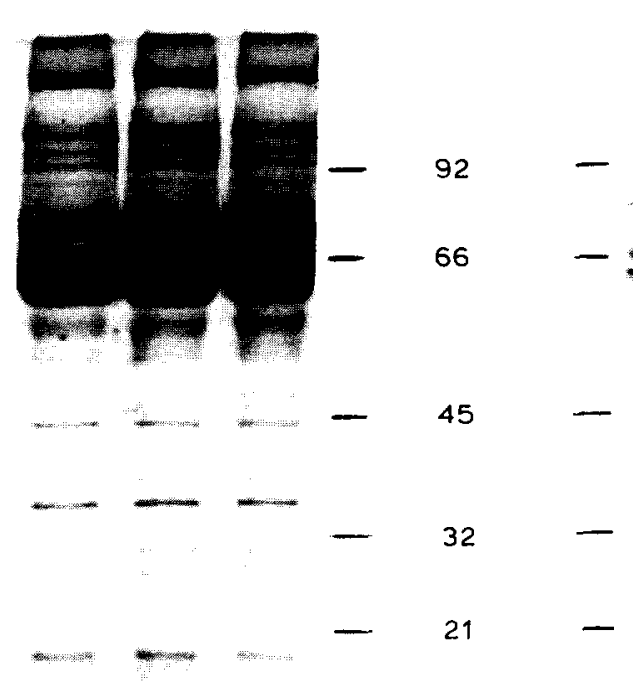

B
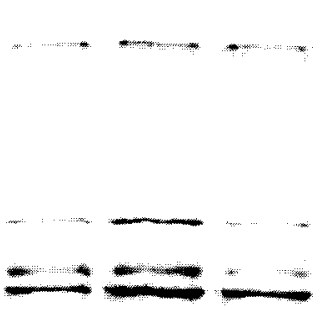

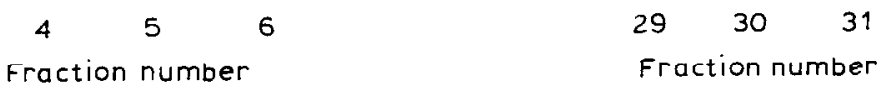

Fig. 3. Analysis of effluent (A) and eluate (B ) fractions by SDS-PAGE. Gels were silverstained by the method of Wray et al. (1981). Marker proteins were used to estimate molecular weights (MW) of viral proteins ( $\mathrm{MW}$ in $\mathrm{Da} \times 10^{-.3}$ ).

tions by HA, FI ISA, SDS-PAGF, and negative contrast electron microscopy indicated the efficiency with which CPV could be purified and concentrated using this method. The possible discrepancy observed between the results obtained with effluent fraction by EM on the one hand and ELISA or HA on the other hand may be explained by the relatively high cutoff values chosen (five times background), and the relative insensitivity of the test, respectively. The possible discrepancy between infectivity and EM results may be explained by the fact that at most only noninfectious or damaged virus particles were present in the effluent. The recovery of CPV antigen, as judged from HA and ELISA titrations was $70-90 \%$, whereas the recovery of infectious CPV, as shown by infectivity titrations, proved to be about $20 \%$. The loss of infectivity probably is a direct effect of the elution conditions used and the procedure of dialysis, followed by freezing and thawing before testing. This was confirmed by testing of CPV culture material 
TABLE 2

Quantitative data of IAC purification and concentration procedure

\begin{tabular}{lcll}
\hline & $\begin{array}{l}\text { Culture } \\
\text { supernatant }\end{array}$ & $\begin{array}{l}\text { Effluent } \\
\text { fractions }\end{array}$ & $\begin{array}{l}\text { Eluate } \\
\text { fractions }\end{array}$ \\
\hline $\begin{array}{l}\text { Volume net }(\mathrm{ml}) \\
\text { Protein concentration }(\mu \mathrm{g} / \mathrm{ml})\end{array}$ & 90 & 1.8 & 1.8 \\
BSA concentration $(\mu \mathrm{g} / \mathrm{ml})$ & 3000 & $<15-3925$ & $<15-40$ \\
HA titer & 1024 & $2.6-3900$ & $0.15-8$ \\
ELISA titer & 30 & 0 & $0-16.000$ \\
Infectivity $\left(\log _{10} \mathrm{TCID}_{5,1} / \mathrm{ml}\right)$ & 4.9 & 0 & $0-730$ \\
EM & & $<1$ & $(90 \%)$ \\
& $+* *$ & & $(20 \%)$ \\
& & - & ++++ \\
\hline
\end{tabular}

* Estimated total recovery.

** Arbitrary units indicating the number of virus particles observed: $+=$ small numbers; $++++=$ large numbers (Fig. 3).

directly treated in the same way (not shown). This reduction in infectivity might partly be overcome by using a procedure of $\mathrm{NH}_{4} \mathrm{SCN}$ gradient elution in combination with gel filtration. Over $99 \%$ of the contaminating proteins were shown to be removed in the IAC procedure, by determination of the reduction of the BSA content in an ELISA, of the total protein content by colorimetry and by comparing the different fractions in SDS-PAGE. Since BSA is the major contaminating protein present in fetal calf serum used in our cell culture system, it may be concluded from our data that the determination of the BSA content may be considered a proper method to validate the purification procedure. The small BSA peak present in the eluate fractions containing most intact CPV particles and infectivity may be explained by a nonspecific binding of BSA to either the affinity column or directly to CPV.

The use of the IAC method described for the purification and concentration of CPV may not only be of interest for the production of purified CPV for biochemical, ultrastructural and immunological studies, but may also be applied to produce infectious CPV or CPV antigen to be used for vaccination purposes or in diagnostic tests. The cross-reactivity of the respective MoAbs with FPV would also offer the opportunity to use these for the same applications with this virus.

A similar approach of IAC using MoAb would also be of interest for the purification of human parvovirus B19, e.g., from viraemic plasma, since no in vitro cultivation systems are available for this virus at present (Siegl, 1984).

\section{Acknowledgements}

The authors wish to thank Ms. M. Burger for technical assitance and Ms. C. Kruyssen for preparation of the manuscript. 


\section{References}

Appel, M.J.G., Scott, F.W. and Carmichael, L.E. (1979) Vet. Rec. 105, 156-159.

Binn, L.N. Marchwicki, R.H. and Stephenson, E.H. (1980) Am. J. Vet. Res. 41, 855-860.

Bradford, M.M. (1976) Anal. Biochem. 72, 248-254.

Burtonboy, G., Bazin, H. and Delferriere, N. (1982) Arch. Virol. 71, 291-302.

Carmichael. L.E., Joubert, J.C. and Pollock. R.V.H. (1981) Cornell Vet. 71, 408-427.

Chong, P. and Gillam, S. (1985) J. Virol. Methods 10. 261-268.

Diaco. R.. Hill, J.H. and Durand, D.P. (1986) J. Gen. Virol. 67, 345-351.

Fiscus, S.A.. Mildbrand, M.M. Gordon. J.C.. Teramoto, Y.A. and Winston. S.. (1985) Am. J. Vet. Res. 46, 859-863.

Gagnon, A.N, and Povey, R.C. (1979) Vet. Rec. 104, 263-264.

Johnson, R.H. and Spradbrow, P.B. (1979) Aust. Vet. 55. 151.

Kenyon, A.J.. Gander, J.E., Lopez. C. and Good. R.A. (1973) Science 179, 187-189.

Laemmli, U.K. (1970) Nature (London) 227, 680-685

Manil, L., Motte, P. Pernas. P.. Troalen, F., Bohuon. C. and Bellet, D. (1986) J. Immunol. Methods $90,25-73$.

Nakane, P.K. and Kawaoi, A. (1974) J. Histochem. Cytochem. 22, 1084.

Osterhaus, A.D.M.E., Van Steenis. G. and De Kreek. P. (1980a) Zentralbl. Veterinaemed. Reihe B $27,11-21$.

Osterhaus. A.D.M.E., Drost. G.A., Wirahadiredja, R.M.S. and Van den Ingh. T.S.G.A.M. (1980b) Vet. Q. 2. 181-236.

Osterhaus. A.D.M.E., Wezel, A.L., Van Steenis, G., Drost. G.A. and Hazendonk, T.G. (1981) Intervirology $16,218-224$.

Paradiso. P.R. (1981) J. Virol. 39, 800-807.

Paradiso, P.R., Rhude, S.L. and Singer, I.I. (1982) J. Gen. Virol. 62, 113-125.

Parrish, C.R. Carmichael, C.E. and Antczak. D.F. (1982) Arch. Virol. 72, 267-278.

Rhode, S.L. (1985) J. Virol. 54, 630-633.

Seppälä, I., Sarvas, H., Peterly, F. and Malrela, O. (1981) Scand. J. Immunol. 14, 335-342.

Siegl, G. (1984) In: The Parvoviruses (Berns, K.I., ed.), p.389. Plenum Press, New York.

Tattersall, P., Cawte, P.J., Shatkin, A.J. and Ward, D.C. (1976) J. Virol. 20, 273-289.

Wray, W., Boulikas, T., Wray, V.P. and Hancock, R. (1981) Anal. Biochem. 118, 197-203. 